\title{
Çalışanın Aşırı Niteliklilik Özelliği İle Örgütsel Sinizm İlişkisinde İyi Oluşunun Aracı Etkisi
}

DOI: 10.26466/opus.804170

\author{
* \\ Cihan Tınaztepe * - Necmiye Tülin İrge ** \\ * Dr. Öğr. Üyesi, İstanbul Aydın Üniversitesi \\ E-Posta: cihantinaztepe@aydin.edu.tr \\ ORCID: 0000-0002-9614-7298 \\ ** Dr. Öğr. Üyesi, İstanbul Aydın Üniversitesi \\ E-Posta: necmiyeirge@aydin.edu.tr \\ ORCID: 0000-0001-9936-6229
}

\section{Öz}

Bu araştırma kantitatif yöntemler kullanılarak çalışanların aşırı niteliklilik algısı ile örgüte karşı sinik tutumları arasındaki ilişkiyi ölçümlemiştir. Bu ilişkiyi açıklamak üzere çalışanın iyi oluş hali aracı değişken olarak araştırma modelinde yer almaktadır. Modeli oluşturan bu üç değişkene ait ölçeklerin yer aldı̆̆̆ anket dijital kanalla farklı sektör ve şirketlerde çalışan beyaz yakalılara ulaştırılmış, toplamda 400 geri dönüş alınmıştır. Analizler sonucunda varsayıldı̆̆ı üzere değişkenler arası anlamlı ilişkilendirme yapılmış ve iyi oluş değişkeninin aracı etkisi tespit edilmiştir. Ancak varsayılanın aksine iyi oluş ile örgütsel sinizm arasında pozitif bir ilişki bulunmuştur. Hipotezlerin test edilmesinin yanı sıra değişkenlerin demografik kırılımları incelenmiş ve literatüre paralel olarak anlamlı farklılıklara rastlanmıştır. Buna göre fark testleri de araştırmada elde edilen bulguların yazını desteklediğini göstermektedir. İyi oluş değişkeninin eğitim seviyesi arttıkça düştü̆ğ̈̈ görülmektedir. Ĕ̆itim seviyesinin artmasıyla örgüte duyulan sinizm ise artmaktadır. Gelir seviyesi açısından farklar göstermektedir ki gelir seviyesi belli bir seviyeye kadar iyi oluşu pekiştirmekte ancak sonrasında etkisi azalmaktadır. İşyerinde yeni olanlar ve ile işinde en yüksek kıdemli olan çalışanların hissettiğ̈i örgütsel sinizm daha yoğundur.

Anahtar Kelimeler: Aşııı Niteliklilik, Örgütsel Sinizm, İyi Oluş 


\title{
The Mediating Role Of Employee Well Being On The Relationship Between Over Qualification And Organizational Cynicism
}

\begin{abstract}
This research has measured the relationship between employees' perception of Over Qualification and their cynic attitude towards organization by using quantitative methods. In order to explain this relationship, the mediating role of employee Well Being takes place in this research model. The survey which contains the scales of these three variables, was sent to white collar employees from different sectors and companies through digital channel. A total of 400 valid responses were received. As a result of analyses, significant relationships were determined among the variables and the mediating effect of Well Being was proved. In contrast to the hypothesis, a positive relationship between Well Being and Organizational Cynicism was found. As well as hypothesis testing, difference tests were conducted for the variables and significant results were found in terms of demographics as similar to the results in literature. A decrease in the well-being as a variable is seen as the level of education increases. As the level of education increases, the cynicism for the organization also climbs up. In terms of difference in income, it is seen that level of income improves the well-being to a certain level, yet this effect fades away, later. New employees and senior employees feel cynicism more densely.
\end{abstract}

Keywords: Over Qualification, Organizational Cynicism, Well Being 


\section{Giriş}

Örgütler işlerini yapabilmek için gereken nitelik düzeyiyle uyumlu olan çal1şanları tercih etmektedirler. Eğitim, tecrübe, beceri gibi nitelikleri işin gerektirdiği nitelikler ile benzeşen çalışanların örgütler için ideal olduğu belirtilmektedir. Bu ideal durum her zaman sağlanamamaktadır. Verilen işi yapabilmek için lisans mezunu olmanın yeterli olduğu bir işte, yüksek lisans veya doktora mezunu bir çalışan kendini farklı bir yerde konumlandırmaktadır. Bu örnekteki açıklama ilgili yazında "overqualification (aşırı niteliklilik)" olarak nitelendirilmektedir (Fine, 2007; Maynard, Joseph ve Maynard, 2006). Aşırı niteliklilik, çalışanların işin gerektirdiği eğitim ve niteliklerden daha fazlasına sahip oldukları durumu ifade etmektedir (Khan ve Morrow, 1991; Verhaest ve Omey, 2006; Green ve McIntosh, 2007).

Sinizm, uzun geçmişe sahip olan, zamanla daha da önem kazanmış ve birçok alanda araştırma konusu olmuş bir kavramdır. İlk olarak kullanıldığı zamanki sinizm kavramı ile şu anda kullanılan sinizm kavramı içerik olarak farklıdır. Geçmişte sinik tutum sahipleri merhameti olmayan eleştirmenler olarak anılmasına rağmen, şimdilerde siniklerin doğuştan kötümser ve güvenilir olmayan bir özelliğe sahip oldukları değerlendirilmektedir (Mantere ve Martinsuo, 2001). Sinik kavramının ortaya çıktı̆̆ ilk zamanlardaki Yunan sinikleri o zamana uygun kurumları eleştirmek için genellikle alaycı bir mizah kullanmaktadır (Delken, 2004, s.12). Ancak literatürde şimdilerde yer alan sinizme dair kavramlar incelendiğinde, sinizmin bir yaşam biçiminden çok bir kişilik özelliği veya tutum olduğu görülmektedir (Eaton, 2000). Sinizm, "insanları zor beğenen, memnuniyetsiz, hadiselere devamlı eleştirel yaklaşan, çıkarları için yaşayan ve negatif düşünceler ile dolu bir düşünce akımı olarak tanımlanmaktadır (Yangil, Baş ve Aygün, 2014). Örgütsel sinizm de çalışma hayatında bireyin çalıştığı örgüte karşı olumsuz tutumu olarak tanımlanmaktadır.

Öznel iyi oluş, mutluluk tanımını, insanları mutlu eden faktörleri, mutlu olmak için ne tür stratejiler kullanılması gerektiğini cevaplamaktadır. Öznel iyi oluş, "insanların yaşamına ilişkin değerlendirmelerinin ve hadielere verdiği duygusal tepkilerin bir sonucu olarak" kabul edilmektedir (Doğan, 2013). Öznel iyi oluş genellikle mutluluk olarak ifade edilmekte ve bir kişinin yaşamından mutlu olması ve hayatından istediği tatmini alması öznel iyi olu- 
şunun bir göstergesi olarak görülmektedir. Öznel iyi oluş, bir kişinin hayattnın bilişsel ve duygusal değerlendirmelerini analiz eder (Diener, 2000). Örgütlerde, işin gereklerine uygun, daha üstün eğitim almış çalışanlar kabiliyet, deneyim ve becerileri bakımından aşırı niteliklilik özelliklerine sahip olmaktadır. Böylece örgütlerinde öznel iyi oluş halleri yüksek ve sinik davranışları düşük çalışanlar olarak nitelendirilebilmektedir. Örgütlerde öznel iyi oluş hali yüksek çalışanların olması olumlu bir örgüt ikliminin oluşmasını sağlar. Öznel iyi oluş hali düşük çalışanlarsa örgütlerine karşı karamsar ve olumsuz bir davranış sergiler. Bu durum örgüt içerisinde çalışanın sinik davranışlar göstermesine neden olur. Bu varsayımların bu çalışmada da sağlanıp sağlanmadığının belirlenmesi için aşırı niteliklilik halinin örgütsel sinizm davranışında çalışan iyi oluşun aracılık etkisi araştırılmaktadır.

\section{Temel Kavramlar}

\section{Aşırı Niteliklilik}

Aşırı niteliklilik, bireyin sürdürdügü işin gereklerine sahip olmasının yanı sıra söz konusu iş gereklerinden daha üstün eğitim almış olmasl; kabiliyet, deneyim ve becerileri bakımından üstün özelliklerinin bulunması durumudur (Akın ve Ulukök, 2016). Aşırı niteliklilik kavramı ülkemizdeki literatürde, üstün niteliklilik ve fazla niteliklilik olarak tanımlanmaktadır (Akbıyık, 2016). Uluslararası literatüre baktığımızda bu kavrama ilk kez 1976 senesinde Richard B. Freeman tarafindan yazılan "The Overeducated America" isimli kitapta rastlanmıştır. Freeman, bu kitapta, iyi eğitim almış işgücünün önemli bir arz fazlası olduğuna, yüksek olasılıkla gelecek seneler süresince bu durumun değişmeyeceğine ve lisans düzeyinde bir diplomaya sahip olmanın değersizleşmesine ilişkin kaygılarını ifade etmiştir (Gizlier, 2018). Bireyin bu durumunu Freeman eksik istihdam olgusu ile açılamıştır (Akın, Ulugök ve Gökdeniz, 2017). Algılanan aşırı niteliklilik bir çalışanın iş gereklerinden daha fazla niteliğe sahip olduğuna dair öznel düşüncedir (Maynard ve Brondolo, 2015). Bu algıyı oluşturan birçok etmen bulunmaktadır. Ekonomik açıdan düşündüğümüzde hem organizasyonlar hem bireyler bu tür bir ilişkiden kaçınmalıdırlar; çünkü bu durum kaynakların yetersizleştirilmesidir. 
Aşrı niteliklilik eksik istihdamın bir çeşididir ve genel olarak baktığımızda nedenlerinden biri de 21.yy'da ekonomideki sıkıntılı süreç ve iş bulma seçeneklerinin az olmasıdır. Bu nedenle aşırı niteliklilik; Amerika, Kanada, Avrupa, Çin gibi gelişmiş ülkelerde göze çarpan bir sorun haline gelmiştir. İstatistiki verilere göre Çin'de çalışanların \%85'i kendilerini bulundukları iş için aşırı nitelikli olarak tanımlamıştır (Zhang, Law ve Lin, 2017).

Aşırı nitelikli çalışanları istihdam etmenin sonuçları verimlilik karşıtı iş davranışları ve yaratıcı performans olarak iki grupta incelenmektedir (Luksyte, 2011). Verimlilik karşıtı iş davranışı örgütsel normların ihlal edildiği, örgüt amacıyla bağdaşmayan davranışları ifade etmektedir. Bunlar; İnternet ve Bilgisayarın İş Amacı Dışında kullanımı, Geri çekilme davranışı (İşe geç kalma, hiç gelmeme ve sonuç olarak da işten gönüllü olarak ayrılma), İşe Geç Gelme Davranışı, İşe Gelmeme Davranışı şeklinde sıralanabilmektedir. Çalışanların yenilikçi davranışları; örgütsel etkinlik ve inovasyonu artırmaktadır, işletmelerin hayatta kalmalarını kolaylaştırmaktadır. Anlamlı düzeyde rekabet ve örgütsel teşvikle aşırı nitelikli çalışanların örgüt lehine davranışlar oluşturmalarının sağlanabileceği düşünülmektedir.

\section{Sinizm}

Türk Dil Kurumu sinizmi; “İnsanın erdem ve mutluluğa, hiçbir değere bağlı olmadan buitün gereksinmelerden siyrilarak kendi kendine erişebileceğini savunan Antisthenes'in öğretisi, kinizm" şeklinde tanımlamıştır (TDK, 2020). Dilimizde tam bir karşılığı olmayan bu kavramın süreç içerisinde; farkettirmeden ve zekice insanlara kötüklük yapan, itimat edilmeyen manalarını barındıran "sinsi" kavramıyla özdeşleştiği kabul edilmektedir (Oğrak ve Erol, 2019).

Sinizm, Antik Yunan falsefesi ve yaşayış biçimi çerçevesinde bireye, herhangi bir topluluğa, öğretiye, örgüte ya da sosyal olarak antlaşmalara karşı güven duymama ve düş kırıklı̆g hissi olarak ifade edilmektedir. Bununla beraber, bireylere ve olaylara karşı sürekli eleştiride bulunan, tatmin olmayan, şahsi menfaatlerini öncelikli gören ve negatif fikirler üreten bireyleri tanımlamada kullanılan bir ideolojidir. Sokrat' in öğrencisi Antishenes sinik ideolojiyi benimseyen ilk kişi olmasına rağmen, öğrencisi Diyojen ideolojinin yayılmasını konusunda Antishenes'i geride bırakmıştır. Sinizmi savunan düşünür- 
lerden birisi de Friedrich Nietzsche'dir. "Böyle Buyurdu Zerdüşt" isimli eserindeki "İnsanlar arasında yaşamayı hayvanlar arasında yaşamaktan daha tehlikeli buldum." cümlesi düşünürün insanlara itimat etmediği ve sinik bir düşünce tarzında olduğunu bizlere sezdirmiştir (Kanat, 2017).

Sinizmi örgütsel anlamda işgörenin organizasyonun kendisine karşı riyakar uygulamalarda bulunduğunu düşünmesi ve bu bağlamda organizasyona karşı olumsuz hisler beslemesi ve olumsuz davranışlarda bulunması örgütsel sinizmdir (Görmen, 2017). Örgütsel sinizm organizasyona karşı zihinsel, hissi ve eylemsel olarak gösterilen olumsuz tutumlardır (Uysal ve Yıldız, 2014). Başka bir örgütsel sinizm tanımı ise kişinin bulunduğu organizasyonda ahlaki değerlerin bulunmadığını ve adalet, doğruluk ve içtenlik kavramlarının organizasyonel menfaatler uğruna göz ardı edildiğini düşünmesi örgütsel sinizmdir (Yalçınkaya, 2014).

Örgütsel sinizmin boyutları; bilişsel, duyuşsal ve davranışsal olarak üçe ayrılabilir (Karacaoğlu ve Küçükköylü, 2015) Duyuşsal boyut psikolojik ve fizyolojik olarak belirli bir duyguya ait fikirleri içermektedir (Kosa, 2019). Sinizmin getirdiği düşünceler neticesinde ortaya çıkan hisler duyuşsal boyut olarak ifade edilmektedir (Tinaztepe, 2012). Bu boyutta münasebetsiz hareketler, kızgınlık, bunalım, utanma, kaygı ve benzeri hisler oraya çıkar (Çetinkaya ve Özkara, 2015). Bu kişiler sübjektif yargılarda bulunur ve bu yargılara sahip olmayan kişileri bireysel düşünceleri açısından yargılar ve eksik olduklarını düşünürler (Karcıoğlu ve Naktiyok, 2015). Bilişsel boyut ağırlıklı olarak inanma, bilgiyi yöneltme ve fikirleri içermektedir (Kosa, 2019). Brandes'e göre bilişsel boyut, kurumun adil olmadığı doğrultusundaki düşüncedir (T1naztepe, 2012). Örgütsel sinizmin bilişsel boyutunda iş gören çalıştığı kurumun dürüst olmadığını düşünür (Çetinkaya ve Özkara, 2015). Örgütlerde sinik davranışlar sergileyen kişilerin organizasyonel prensip, kaide ve görevleri önemsemeyen, çelişkili tutuma sahip, hiç kimseye itimat etmeyen, bireysel menfaatlerini ön planda tutan kişiler olduğu gözlemlenmektedir (Elçi ve Kul, 2017). Davranışsal boyut uyarıcıya karşı davranışsal reaksiyondur şeklinde tanımlanabilir (Kosa, 2019). Sinik olarak kabul edilen iş görenler, organizasyonun akıbeti konusunda kötümser tahminlerde bulunurlar ve bu durumda diğer bireyleri aşağılayıcı hareketler yapabilirler (Tınaztepe, 2012). Bu boyutta iş gören kurumsal politikalardan sürekli yakınma, alay etme, tenkit etme gibi eylemlerde bulunur (Çetinkaya ve Özkara, 2015). 
Kişilik sinizmi kişinin kendi karakter özellikleri nedeniyle ortaya çıkarken örgütsel sinizm örgüt kaynaklı nedenlerle ortaya çıkar (Akbolat, Işık ve Kahraman, 2014). Bu kavramları ayrı ayrı incelemekte yarar vardır. Sinizmin nedenleri kişilik sinizmi ve örgütsel sinizm olarak iki ayrı başlıkta incelenmektedir. Kişilik sinizmi genetik ve sabit olup kişinin iç dünyasıyla alakalıdır ve kişi diğer bireylerin menfaatçi, yalancı, egoist özellikler taşıdığı kanaatindedir. Bu tür kişilerle diğer bireyler arasında olumsuz tutumlar ve yerleşmiş bir güvensizlik hali bulunmaktadır (Yücel ve Çetinkaya, 2015). Sinik özellik taşıyan kişiler, bulundukları örgütte ilkeli davranılmadığına inanırlar, diğer bireyleri hafife alırlar ve bulundukları yerdeki bireylerin eylemlerini tutarsız ve itimat edilmez bulurlar (Karacaoğlu ve İnce, 2012).

Kişilik sinizmiyle örgütsel sinizm ilişkisine bakıldığında, kişilik sinizminin karakter özelliği ile alakalı olduğu, örgütsel sinizmde ise örgüt kaynaklı nedenlerin kişide sinik davranışlara sebep olduğu saptanmıştır (Turan, 2011).

Sinizm konusu ile alakalı çalışmalara bakıldığında teknolojik farklılaşmanın sonucunda işletmelerin rakiplerinden üstün gelme çabalarl, mali krizler, işgören maaşlarındaki yetersizlik, mesai saatlerinin gereğinden fazla olması gibi nedenler işgörenlerin organizasyona negatif düşünceler oluşturmasına neden olmaktadır (Akyüz, 2015). Örgütsel sinizm; örgütsel alaycılık ve adaletsiz davranışların artması, örgütsel desteğin azalması, psikolojik sözleşme ihlali ve lider ya da yöneticilerin kurumlardaki etkisizliği gibi birçok faktöre bağlı olarak ortaya çıkabilmektedir (Gökyer ve Türkoğlu, 2018). Dean kurumlarda örgütsel sinizmi çoğaltan etmenler arasında kompleks ve farklılaşmanın fazla olduğu organizasyonlarda, sıradan ve tekdüze organizasyonlara göre görülme olasılığının daha fazla olduğu, dışa bağımlılığı olmayan kurumlarda örgütsel sinizmin daha az ortaya çıktığı ve üst yönetimin kurum dışından atandığı kurumlarda örgütsel sinizme daha çok rastlandığı sayılmaktadır (Erdoğan ve Bedük, 2013):

Bunların dışında örgütlerde sinizme yol açan sebeplerden bazılarl; yönetimsel değişime yönelik hatalı uygulamalar, bireyde yüksek gerginliğe yol açan görevler, bireysel ve organizasyonel isteklerin gerçekleşmemesi, sosyal yardımların az olması, görevde yükselme olanaklarının kısıtlı olması, işten çıkarmalar, iletişim sorunları şeklinde sıralanabilmektedir (Balay, Kaya ve Cülha, 2013). Örgütsel sinizm ile ilgili çalışmalar oldukça yenidir ve maalesef örgütsel sinizmin nedenlerine ilişkin kesin ve net cevaplar bulunmamaktadır. 
Buna ek olarak bireysel sinizmin nedenleri konusunda da fikir birliği olmamasından dolayı örgütsel sinizmin nedenlerini tartışmak özellikle zor olmaktadır (Volpe, 2011).

\section{İyi Oluş}

Tarih boyunca insanlar iyi bir hayat sürmenin ve hayat kalitesini yükseltmenin nasıl mümkün olabileceğini merak etmişlerdir. Bireylerin yaşamayı istedikleri hayata ilişkin fikir ve duyguları, bireyin hayatının yaşanılası, haz verici ve iyi olmasına ilişkin sübjektif düşünceleri içermekte ve öznel iyi oluşu meydana getirmektedir (Usta, 2016).

Literatürde "Öznel iyi oluş" kavramı 1970 senesinden beri çokça yer almaktadır. "Öznel iyi oluş" çoğunlukla psikoloji biliminde ele alınan ve bireyin yaşamıyla ilgili ne düşündüğü ve bu konudaki duygularının neler olduğuna ilişkin olarak kullanılan bir kavramdır. Costa ve McCrea 1980'de yaptıkları araştırma ile "Öznel iyi oluş" konusunun araştırılmasına önderlik etmişlerdir. Öznel iyi oluş kavramının karakterle ilintili olduğu fikrini savunan araştırmacılar sonuç olarak dışa dönük ve nevrotik olmanın öznel iyi oluşu etkilediğini bulmuşlardır. Ancak modelin, kişilik birliği ve demografik değişkenler ve sosyal ağlar olmak üzere iki sınırlılığı olduğunu belirtmişlerdir (Günay, Çetinceli ve Özdemir, 2018). "Öznel iyi oluş" kavramının boyutları "bilişsel" ve "duygusal" olmak üzere ikiye ayrılmaktadır. "Bilişsel" faktör bireyin bulunulan zamandaki ve geçmişteki hayatına ilişkin tatmindir. "Duygusal" boyut ise bireyin bulunulan zamandaki ve geçmişteki hayatına ilişkin pozitif ve negatif hislerini içermektedir (Kiremitçi ve Coşkun, 2017). Birçok araştırmacı ve sanatçı tarafından merak edilen ve incelenen bir konu olan öznel iyi oluş, yani mutluluk üzerine birçok yargiya varılmıştır. Örneğin Yusuf has Hacib'in "Kutadgu Bilig"' adlı eseri Türkçeye "Mutluluk Veren Bilgi" olarak çevrilmiştir (Bozkırli, 2013).

Öznel iyi oluşu ele alan birçok teori vardır. Örneğin Erek Teorisi Wilson tarafından geliştirilmiş olup, teori çerçevesinden baktığımızda iyi oluş ve mutlu olmanın herhengi bir hedef ya da ihtiyaçla ilgili olup bunların giderilmesi durumunda oluşabileceği düşünülmektedir (Satan, 2014). Erek teorisinde, insanların belirli bir amacı gerçekleştirebildiğinde ya da gereksinimi giderdiğinde mutlu olabildiği görüşü savunulur. Ryff ve Singer Tarafından 1996'da ifade ettiği "psikolojik iyi oluş" kavramı ve Ryan ve Denci tarafından 
2000 yılında ortaya konan "öz belirleme teorisi" gibi ihtiyaç teorileri, bireyin iyi oluşu gerçekleştirebilmesi için yapılması zorunlu yaradılıştan kaynaklı gereksinimler bulunduğunu ifade etmektedir (Diener ve Ryan, 2018).

Aşağıdan Yukarı (Bottom Up) ve Yukarıdan Aşağı (Top Down) Teorisine göre ise; kişiye mutlu olup olmadığı sorulduğunda; kişi deneyimlemiş olduğu zevk ve acının miktarını mukayese ederek soruyu cevaplar (Eryılmaz, 2009). Bu teori öznel iyi oluşun temelini felsefi atomistik düşüncenin oluşturduğunu ve özel iyi oluşun bireyin kişiliği ile ilgili olduğunu savunmaktadır. Öznel iyi oluş bireyde gelişen içsel bir süreçtir ve bu durumun neticesinde bireyin yaşamda karşılaştığı olaylara yüklediği anlam öznel iyi oluşunu etkilemektedir (Öztürk, 2017). Etkinlik Teorisi bağlamında ise mutlu olma, bireyin etkin olmasının bir sonucudur ve kişi hedeflerine erişmek maksadiyla gerçekleştirdiği etkinlik neticesinde tatmin hissi yaşamaktadır. Akış Teorisi de bireyin yetenek seviyesinin yeterli olması durumunda etkinlik ve söz konusu etkinlik engellerinin süreçteki akışının kişiye zevk verdiğini ileri sürmektedir. Sonuç olarak yapılan etkinlik kişi açısından basit bulunursa sıkıcı olmakta, gerçekleştirmesinin aşırı güç olması durumunda ise kişinin endişe duymasına neden olmaktadır (Osmanoğlu ve Kaya, 2013).

Ryff'in Psikolojik İyi Oluş Teorisi 1986 yılında Ryff tarafından yapılmış olan araştırmada "iyi oluş" kavramının mutlu olmaktan çok kişisel gelişim olarak algılanmasının öneminin altını çizmiştir. Bu durumun sonucunda iyi oluşa ilişkin araştırmalarda iyi oluş kavramı; diğerleri ile pozitif ilişki, çevreye hakim olma, otonomi, kendini geliştirme, hayata ilişkin hedefler, kendini kabul etmek gibi başlıklar altında incelenmektedir (Kuyumcu ve Güven, 2012). Diğerleri ile pozitif ilişki; kişinin diğer bireylerle anlamlı münasebet ve iletişimin olmasıdır. Çevreye hakim olma; kişinin hayatını ve çevresini etkin bir biçimde yönlendirebilme yeteneğidir. Otonomi, hür irade duygusunu ifade etmektedir. Kendini geliştirme; kişisel gelişimin devamlılığıdır. Hayata ilişkin hedefler; kişinin hayatında bir gayenin bulunduğuna ve hayatının anlamlı olduğuna ilişkin düşüncesidir. Kendini kabul etme; bireyin hayatını ve benliğini olumlu algılamasıdır (Akdağ ve Çankaya, 2015). Yargı Kuramları (Judgment Theories)'ndan biri olan ve Michalos tarafından 1985 yılında geliştirilen Çok Yönlü Uyuşmazlık kuramına göre kişilerin durumlarını farklı bireylerle, eskiden varolan şartlarla, arzu ve tatminin optimum seviyesini, gereksinim ve hedefler gibi bir çok kriteri göz önünde bulundurup karşılaştır- 
dıklarını savunur. Bununla beraber bu kuramda demografik faktörlerle kişinin öznel iyi oluşu arasında ilişki olduğu savunulsa da aksini savunan çalışmalar da literatürde mevcuttur (Şahin, 2011). Sosyal Karşılaştırma Kuramında ise bireyin diğerlerinin durumunu göz önüne alarak kendi bulunduğu koşullarla mukayese ederek öznel iyi oluş yargısına sahip olduğu düşünülmektedir. Öznel iyi oluşun seviyesi bireyin referans aldığı grupta durumunun öteki bireylerden iyi durumda olduğunu düşünüyorsa yükselmekte, kötü durumda olduğunu düşünüyorsa düşmektedir. Kısaca bireyin öznel iyi oluşu kendi durumundan daha iyi ya da kötü olan bireyler çerçevesinde oluşmaktadır (Duran, 2014).

\section{Literatür, Hipotezler ve Araştırma Modeli}

Literatürde çalışanın aşırı niteliklilik özelliklerinin örgütüne karşı sinik tutumunda çalışanın iyi oluşunun aracılık etkisini araştıran araştırmalar yer almamaktadır. Örgütsel sinizmin başka bir değişkenle ilişkisinde çalışanın öznel iyi oluşunun rolü üzerine bir çalışma yer alırken, araştırmada kullandı̆̆gmız üç değişkeninin başka değişkenlerle ilişkisi ve etkisine bakılmıştır.

Örgütlerde, işin gereklerine uygun, daha üstün eğitim almış çalışanlar kabiliyet, deneyim ve becerileri bakımından aşırı niteliklik özelliklerine sahip olmaktadır. Böylece örgütlerinde öznel iyi oluş halleri yüksek ve sinik davranışları düşük çalışanlar olarak nitelendirilebilmektedir. Örgütlerde öznel iyi oluş hali yüksek çalışanların olması olumlu bir örgüt ikliminin oluşmasını sağlar. Öznel iyi oluş hali düşük çalışanlarsa örgütlerine karşı karamsar ve olumsuz bir davranış sergiler. Bu durum örgüt içerisinde çalışanın sinik davranışlar göstermesine neden olur. Bu varsayımlar doğrultusunda değişkenler arasındaki ilişkileri tespit etmek üzere araştırmanın hipotezleri aşağıdaki gibi oluşturulmuştur:

- H1: Çalışanın aşırı nitelikli olduğu düşüncesi, örgüte karşı sinik tutumunu arttırır.

- H2: Aşırı niteliklilik düşüncesi, çalışanın daha iyi hissetmesini sağlar.

- H3: Çalışanın daha iyi hissetmesi, örgüte karşı sinik tutumunun azalmasina neden olur.

- H4: Aşırı niteliklilik özelliği, çalışanın iyi oluşu aracıllğıyla örgütsel sinizmi etkiler. 


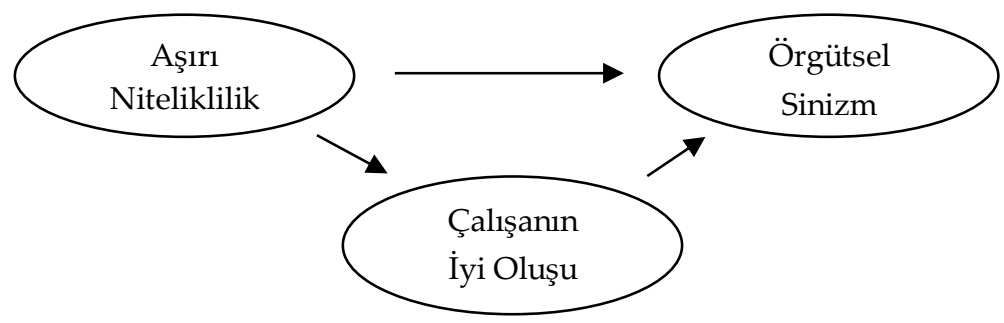

Şekil 1. Araştırma Modeli

\section{Araştırma Yöntemi}

Söz konusu araştırma kantitatif yöntemle gerçekleştirilmiştir. Değişkenlerin ölçüm araçlarının geçerliliği tespit edildikten sonra istatistiki analizlerle örneklem yapısı incelenmiş, hipotezler test edilmiş ve verilerdeki demografik farklılıklara dikkat çekilmiştir.

\section{Ölçüm Süreci ve Araçlarn}

Araştırmada kullanılan anket; demografi, İyi Oluş, Aşırı Niteliklilik ve Örgütsel Sinizm olmak üzere üç bölümden oluşmaktadır. 2019 Aralık ayında uygulanan anketin, demografi hariç tüm soruları beşli Likert skalası ile ölçümlenmiştir (1=Kesinlikle katılmıyorum, 5=Kesinlikle katılıyorum). Çalışmanın analiz birimi farklı sektör ve işletmelerde çalışan bireylerdir. Çoğu Örgütsel Davranış alanındaki çalışmalarda olduğu gibi bu çalışma da mikro analiz düzeyinde kurgulanmıştır. Bu anket elektronik bir ortamda hazırlanıp linki bir beyaz yakalı çalışan panelinde paylaşılmıştır. Elde edilen cevaplar elektronik ortamda toplanmış ve sonrasında SPSS programı ile analiz edilmiştir.

Aşırı Niteliklilik değişkeni, Maynard, Joseph ve Maynard (2006) tarafından geliştirilen dokuz soru ile ölçümlenmiştir. Ölçeğin Türkçe uyarlaması Yıldız vd., (2017) tarafından yapılmış ve güvenilirliği ile geçerliliği sağlanmıştır. Katılımcılara mevcut çalıştıkları veya en son çalıştıkları kurumu düşünerek kendileri ve yaptıkları işle ilgili ifadelere katılım dereceleri sorulmuştur. Yabancı literatürde Maynard ve arkadaşlarının geliştirdiği ölçek tek boyutlu olarak ele alınırken Türkçe çalışmalarda bu ölçeğin iki faktörlü olduğu görül- 
mektedir (Yıldız vd., 2017; Gizlier, 2018). Söz konusu Türkçe çalışmalarda ölçeğin kendisi ve alt boyutlarının Cronbach Alpha iç tutarlılık katsayıları $\alpha=0,82$ - $\alpha=0,85$ arasında olduğu tespit edilmiştir.

Ankette yer alan ikinci ölçek çalışanların algıladıkları mutluluk düzeyini belirlemek üzere Hills ve Argyle (2002) tarafından geliştirilen ve öncelikle Erkuş, Ünlüer ve Bülbül'ün (2015), sonra da Akdeniz'in (2016) Türkçe yazında kullandığı 18 soruluk bir ölçektir. Bu ölçek ile İyi Oluş değişkeni ölçümlenmiştir. Mutluluk ve öznel iyi olma gerek gündelik ifadelerde gerekse bilimsel literatürde birbirlerinin yerlerine kullanılabilen kavram olduğu bilinmektedir (Diener, 2000; Diener, 1994; akt. Yeşiltaş, Şahin ve Serezli, 2019). Dolay1sıyla çalışanların iyi oluş halleri, mutluluk düzeyleriyle ilişkilendirilerek ölçümlenmiştir. Ölçeğin güvenilirlik düzeyi Erkuş, Ünlüer ve Bülbül'ün (2015) çalışmasında $\alpha=0,92$ olarak belirtilmiştir.

Anketin son ölçeği Örgüt Sinizm değişkenini ölçmektedir. Bilişsel, duyuşsal ve davranışsal olmak üzere üç boyuttan oluşmuş 13 soruluk bir ölçek olan Örgütsel Sinizm; Brandes, Dharwadkar ve Dean (1999) tarafından oluşturulmuştur. Türkiye' de ise Örgütsel Sinizm ölçeğinin faktör yapısının ve psikometrik özelliklerinin incelenmesi, ilk olarak Erdost, Karacaoğlu ve Reyhanoğlu (2007) tarafından gerçekleştirilmiştir. Brandes, Dharwadkar ve Dean ilk çalışmasından ölçeğin alt boyutlarının güvenilirlik düzeylerinin 0,86 ile 0,78 arasında olduğu bilinmektedir.

\section{Örneklem Yapisı}

Araştırma kapsamında kolayda örnekleme yöntemi kullanılarak beyaz yakalı çalışanlara ulaşılmıştır. Toplamda 400 geçerli anket cevaplayan örneklemin yaş ortalaması 35'dir. \%56'sı erkeklerden oluşan bu grubun büyük çoğunluğu yüksek eğitimlidir (\%63, üniversite; \%33 lisansüstü mezunu).

Çalışanların \%39'u iş hayatlarında 10 yıldan fazla süre geçirmişken, \%32'si 6-10 yıllık, \%16'sı 2-5 yıllık ve \%13'u 2 yıldan az süreli kıdeme sahiptir. Mevcut işyerlerinde ise çalışanların \%9'u 10 yıldan fazla, \%29'u 6-10 yıl arası, \%34'ü 2-5 yıl ve \%28'i 2 yıldan az süredir çalışmaktadır.

Son olarak çalışanlara özellikle aşırı niteliklilik açısından farkı gözlemlemek üzere aylık gelir düzeyleri sorulmuştur. Örneklemin \%4'ü bu soruya cevap vermezken, \%42'si 2500-5000TL aras1, \%46's1 5000-7500TL arasi gelirlerinin olduğunu belirtmiştir. 


\section{Bulgular}

Toplanan verilerden anlamlı bulgular elde etmek üzere öncelikle değişkenlerin ölçümlerinin güvenilirliği ve geçerliliği teyit edilmiştir. Bunun için ilk olarak önceden geçerliliği test edilen ölçekler Açımlayıcı Faktör Analizi (AFA) ile alt faktörlere indirgenerek diğer analizlere hazır hale getirilmiştir. Ardından hipotezler regresyon analiziyle test edilmiş ve parametrik olmayan testlerle sonuçlarda anlamlı farklılıklara dikkat edilmiştir.

\section{Değişkenler ve Güvenilirlikleri}

Araştırma modelinin bağımsız değişkeni olan aşırı niteliklilik ölçeğinin maddelerine yönelik yapılan faktör analizi neticesinde KMO değeri 0,808 bulunmuştur. Böylelikle bu ölçeğin faktör analizine uygun olduğunu ve ölçülen özelliğin, örneklemin seçildiği evrende çok boyutluluk özelliği taşıdığını göstermektedir $\left(X^{2}=2319,566 ; s d=36\right.$ ve $\left.p<0,001\right)$. Veri grubu için yapılan Bartlett Küresellik testi sonucu $p<, 001$ bulunduğundan, ölçeğin maddeleri arasında anlamı bir ilişki olduğu da anlaşılmaktadır. Faktör analizi sonucu aşırı niteliklilik değişkeni iki alt boyuta ayrılmıştır. Diğer Türkçe çalışmalarda (Yıldız vd., 2017; Gizlier, 2018) olduğu gibi “kendini üstün görme" ve "işini küu̧ük görme" olarak adlandırılmıştır. Bu faktörler toplamda değişken varyansın \%71'ini açıklamaktadır. \%40-60 aralığında değişen varyans oranlarının sosyal bilimlerde ideal kabul edildiği (Erdoğan vd., 2011; Çokluk vd., 2010) düşünülürse bu araştırma sonucunda elde edilen \%71'lik varyans oranının oldukça tatminkar olduğu söylenebilir. Her iki faktörü oluşturan maddelerin arasında güvenirliğin oldukça yüksek olduğunu göstermektedir $(\alpha$ isşini kụ̈üu görme $-0,867$ ve $\alpha$ kendini üstün görme $=0,856$ ).

Ara değişken olan İyi Oluş, birkaç iterasyondan sonra AFA sonucunda KMO değeri 0,795 bulunmuştur ( $X^{2}=3615,607$; sd=105 ve $\left.p<0,001\right)$. Her ne kadar ölçeğin Türkçe uyarlamasında diğer çalışmalarda (Erkuş, Ünlüer ve Bülbül, 2015; Akdeniz, 2016) değişken tek faktörlü olarak ele alınsa da mevcut çalışmada değişkenin çok boyutlu olduğu görülmüsstür. Faktör ağırlığı farklı faktörlerde birbirine yakın olan sorular çıkarılıp tekrar faktör analizi uygulandığında faktör üç boyuta indirgenmiştir: İşten Memnuniyet, Yaşamdan Memnuniyet ve Kendinden Memnuniyet. AFA değerlerinden ölçeğin üç boyutlu olarak analiz edilmesine elverişli olduğu $\left(X^{2}=3615,607\right.$; sd $=105$ ve $\mathrm{p}<0,001$ ) anlaşılmıştır. Buna göre bu üç faktör değişkenin toplam varyansının 


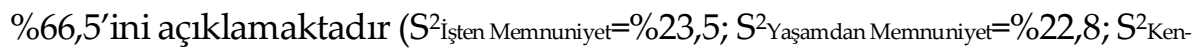
dinden Memnuniyet $=\% 20,3)$. Güvenilirlik analizine geçilmeden bazı faktörlerde anlam bütünlüğünü sağlamak adına bazı soruların bulunduğu faktörler değiştirilmiştir. Faktör analizinde faktör ağırlıkları yeterli olan soruların uygun faktörlere taşınması araştırmacının karar vermesi gereken bir konudur (Sipahi, Yutkoru ve Çinko, 2008). Buna göre modifiye edilen faktörlerin güvenilirlik analizleri yapılmış ve bu şekilde tüm faktörlerin iç tutarlılık katsayıları analizlere devam etmek için yeterli bulunmuştur ( $\alpha$ işsten Memnuniyet $=0,826$; $\alpha$ Yaşamdan Memnuniye $=\% 0,866$ ve $\alpha$ Kendinden Memnuniyet $=0,789)$.

Son olarak modelin bağımlı değişkeni olan örgütsel sinizm AFA analizine tabi tutulmuş ve uygun $\mathrm{KMO}$ testi $\left(\mathrm{KMO}=0,801 ; \mathrm{X}^{2}=4605,742\right.$; $\mathrm{sd}=78$ ve p<0,001) değerleri ile birlikte literatürde (Brandes vd., 1999) olduğu gibi üç faktöre ayrılmıştır. Duyuşsal sinizm, değişken varyansını \%34; Bilişsel sinizm, \%22,5 ve Davranışsal sinizm \%19,5'unu açıklayarak aktör analizi sonucu toplam varyansın \%76'sı açıklanmıştır. Bu faktörlerin iç tutarlılık katsayıları makul düzeyde olduğu tespit edilmiş ( $\alpha$ Duyuşsal sinizm=0,939; $\alpha$ Bilisssel sinizm $=0,848$ ve $\alpha$ Davranıssal sinizm $=0,804$ ) ve analizlere hazır hale getirilmiştir.

\section{Hipotez Testleri}

Araştırma hipotezleri nedensel ilişkileri test etmeye yönelik varsayımlardan oluştuğu için regregresyon analizi uygulanmıştır. Illk üç hipotez basit doğrusal regresyon ile gerçekleştirilirken, ara değişken etkisi varsayan son hipotez için çoklu regresyon analizi uygulanmıştır.

Regresyon analizinden önce değişkenler ve alt faktörleri arasındaki ilişkileri incelemek üzere öncelikle değişkenler arası korelasyon analizi gerçekleştirmek gereklidir. Korelasyon analizi gerçekleştirmeden önce değişkenlerin normal dağılım gösterip göstermedikleri Kolmogorov-Smirnov testi ile incelenmiştir. Bu teste göre her grup için anlamlılık değerleri 0,05'den küçük olduğundan H0 hipotezi reddedilerek (Sipahi, Yurtkoru ve Çinko, 2008), \%95 güvenle verilerin normal dağılmadığı tespit edilmiştir. Bu sebeple söz konusu korelasyon analizinde başvurulan bağıntı katsayısı Spearman'ın rho katsayısıdır. Bağıntı katsayısı "r" (-) 1 ile (+)1 arasında değissen korelasyon analizinde 0,5 düzeyi ve altındakiler zayıf ilişki veya ilişkisiz olarak bilindiği için (Kılıç, 2012); 0,5-0,7 kuvveti arasında değişen orta düzeyde ilişki veya 0,70,9 arasında iyi düzeydeki ilişkilere bakılmıştır. Buna göre iyi oluş ile aşırı 
niteliklilik arasında orta düzeyde $(r=0,553)$ ilişki tespit edilmiştir. İyi Oluşun alt faktörlerinden yaşamla ilgili iyi oluş ile aşırı niteliklilik en yüksek ilişki katsayısına sahip bir korelasyon olduğu $(\mathrm{r}=0,876)$ olduğu görülmüsstür.

İlk hipotez olan aşırı niteliklilik düşüncesinin, örgüte karşı sinik tutumu arttırdığı yöndeki varsayım basit doğrusal regresyonla test edilmiş ve anlamlı olarak hipotezin desteklendiği görülmüştür $(\beta=0,106$; $\mathrm{p}<0,05)$; (Tablo 1, Model 2). Buna göre aşırı nitelikliliğin örgütsel sinizmi açılama gücü $\mathrm{R} 2=0,010$ 'dur. Bu demektir ki; aşırı niteliklilk örgütsel sinizmin \%10 varyansını açıklamaktadır.

İkinci hipotez olan aşırı niteliklilik düşüncesinin, çalışanın daha iyi hissetmesini sağlaması Tablo 1'deki Model 1'e göre yine anlamlı olarak desteklenmiştir $(\beta=0,402 ; p<0,05)$. Bu modelin açıklayıcılık gücü $R^{2}=0,406$ ' dır; yani aşırı niteliklilik değişkeni iyi oluşun \%40 varyansını açıklayabilmektedir.

Üçüncü hipotezde çalışanın iyi hissetmesinin, örgüte karşı sinik tutumunun azaltacağı yönde bir negatif ilişki varsayımında bulunulmuştur. Ancak regresyon analizi bu ilişkinin pozitif yönde anlamlı olduğunu ortaya çıkartmıştır $\left(\beta=0,255 ; p<0,05 ; R^{2}=0,023\right)$. Buna göre üçüncü hipotez reddedilmiştir.

Son hipotezde ise iyi oluş değişkeninin aşırı niteliklilik ile örgütsel sinizm arasındaki aracı etkisi test edilmiştir (Tablo 1). Bunun için uygulanan çoklu regresyon analizinde Baron ve Kenny'nin (1986) üç aşamalı yöntemi kullanılmıştır. Buna göre Model 1'de bağımsız değişken olan aşırı niteliklilik ara değişken olan iyi oluş üzerinde anlamlı etkili olduğu görülmektedir. Sonraki aşama olan Model 2'de bağımsız değişkenin (aşırı niteliklilik) bağımlı değişken (örgütsel sinizm) üzerindeki etkisi ispatlanmıştır. Son aşamada ise bağımsız değişken ile ara değişkenin (iyi oluş) birlikte bağımlı değişken üzerindeki etkisi test edilmiştir. Burada bağımlı değişken üzerinde ara değişkenin anlamlı etkisi olduğu $(\beta=0,150 ; p<0,05)$ ve bağımsız değişkenin etkisinin kaybolduğu $(\mathrm{p}>0,05)$ görülmektedir. Dolayısıyla modelde tam ara değişken etkisinden bahsedilebilir.

Sonuç olarak araştırmanın dört hipotezinden üçü desteklenmektedir. Desteklenmeyen hipotezde ise söz konusu değişkenler arası anlamlı bir nedensel bir ilişki mevcuttur, ancak ilişkinin şekli varsayılanın aksine pozitiftir. 
Tablo 1. Çok Aşamalı Regresyon Analizi

\begin{tabular}{llllll}
\hline & BağımsıDeğişken & Bağımlı Değişken & Beta & t & P \\
\hline $\begin{array}{l}\text { Model 1 } \\
\mathrm{R}=, 637 ; \mathrm{R} 2=, 406 ; \mathrm{F}=272,207 ; \mathrm{p}=, 000\end{array}$ & Aşırı Niteliklilik & İyi Oluş &, 402 & 16,449 &, 000 \\
\hline $\begin{array}{l}\text { Model 2 } \\
\mathrm{R}=, 101 ; \mathrm{R} 2=, 010 ; \mathrm{F}=4,085 ; \mathrm{p}=, 044\end{array}$ & Aşırı Niteliklilik & Örgütsel Sinizm &, 106 & 2,021 &, 044 \\
\hline \multirow{2}{*}{ Model 3 } & Aşırı Niteliklilik & \multirow{2}{*}{ Örgütsel Sinizm } &, 005 &, 085 &, 932 \\
$\mathrm{R}=, 153 ; \mathrm{R} 2=, 023 ; \mathrm{F}=4,766 ; \mathrm{p}=, 009$ & İyi Oluş & & & & \\
\hline
\end{tabular}

\section{Fark Testleri}

Anket sorularının başında yer alan demografik bilgilere göre örneklem gruplar halinde incelenmiş ve bu grupların değişkenler açısından anlamlı farklılıklarına işaret edilmiştir. Normal dağılım göstermeyen mevcut veri setinde ancak ikiden fazla kategorik grupların anlamlı farklılıkları ortaya çıkmıştır. Bunun için parametrik olmayan Kruskal Wallis analizi kullanılarak gruplar arasındaki farklar ortalama değerlere göre incelenmiştir. Tablo 2'deki fark testleri Kruskal Wallis analizinde anlamlı sonuçlar $(p<0,00)$ alınan farklılıkladir.

Buna göre ilk farklılık eğitim seviyesi açısından tespit edilmiştir. Tablo 2'de görüldüğü üzere tüm araştırma değişkenleri eğitim seviyesine göre farklılık göstermektedir. İyi Oluş değişkeni eğitim seviyesi arttıkça düşmekte $\left(X_{\text {lise }}=243,71 ; X_{\text {üniversite }}=218,94 ; X_{\text {lisansüstu }}=159,41\right)$, Örgütsel Sinizm ise artış göstermektedir $\left(X_{\text {lise }}=94,79 ; X_{\text {üniversite }}=203,86\right.$; $X_{\text {lisansüstu }=207,75)}$. Son olarak Aşırı Nitelikliğin en fazla üniversite mezunlarında ön plana çıkması ( $X_{\text {lise }}=159,71 ; X_{\text {üni- }}$ versite $=229,52$; $X_{\text {lisansüstiu }}=149,96$ ) dikkat çekicidir.

Gelir seviyesi açısından da tüm değişkenlerin farklılık gösterdiği görülmektedir. Çalışanların iyi olmaları gelir seviyesi arttıkça artmakta, ancak belli

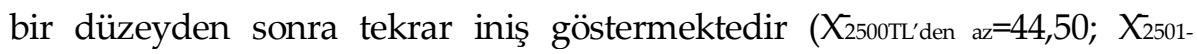
5000тL $\left.=169,75 ; X_{5001-7500 T L}=223,39 ; X_{7500 T L}=166,50\right)$. Örgütsel sinizmde ise en yük-

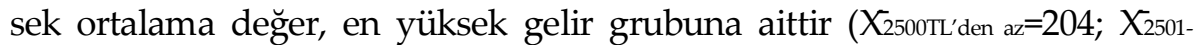

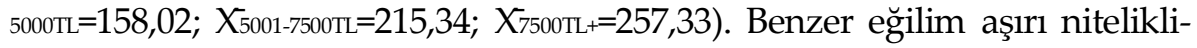
likte de görülmektedir. Buna göre gelir düzeyi yüksek olanlar aşırı niteliklilik algıları daha yüksektir $\quad\left(X_{2500 T L ' d e n}{ }_{\text {az }}=138,50 ; \quad X_{2501-5000 T L}=135,96 ; \quad X_{5001-}\right.$ 7500TL $=231,73 ; X_{7500 T L}=309,50$ ).

Kıdem düzeyi, çalışanın iş hayatındaki genel kıdem ve mevcut bulunduğu işyerindeki kıdem süresi olarak iki farklı kategoride incelenmiştir. Ça- 
lışanın aşırı niteliklilik algısı hayatı boyunca sürdürdüğ̈ kıdem boyunca artmaktadır $\left(X_{2 \text { yldan az }}=148,25 ; X_{2-5}\right.$ yl $=184,91 ; X_{6-10 ~ y l}=208,26 ; X_{10}$ ylt $\left.=218,54\right)$. Örgütsel sinizm ise mevcut işyerinde kıdem süresi üzerinde $U$ şeklinde bir ilişki göstermektedir. Diğer bir deyişle bu bulguya göre örgütsel sinizm işyerinde geçirilen sürenin başlarında yüksekken, ortalarında azalmakta, süre ilerledikçe yeniden artış göstermektedir $\left(X_{2}\right.$ yldan az $=253,00 ; X_{2-5}$ yl $=190,23 ; X_{6-10}$ $\mathrm{yl}=156,26 ; X_{10}$ ylt $=217,50$ ).

Tablo 2. Parametrik Olmayan Fark Testleri

\begin{tabular}{|c|c|c|c|c|}
\hline & Eğitim Düzeyi & Ortalama & p değeri & Ki-Kare \\
\hline \multirow{3}{*}{ İyi Oluş } & Lise & 243,71 & \multirow{3}{*}{0,000} & \multirow{3}{*}{25,346} \\
\hline & Üniversite & 218,94 & & \\
\hline & Lisans üstü & 159,41 & & \\
\hline \multirow{3}{*}{ Örgütsel Sinizm } & Lise & 94,79 & \multirow{3}{*}{0,001} & \multirow{3}{*}{14,960} \\
\hline & Üniversite & 203,86 & & \\
\hline & Lisans üstü & 207,75 & & \\
\hline \multirow{4}{*}{ Aşırı Niteliklilik } & Lise & 159,71 & \multirow{3}{*}{0,000} & \multirow{3}{*}{43,082} \\
\hline & Üniversite & 229,52 & & \\
\hline & Lisans üstü & 149,96 & & \\
\hline & Gelir Seviyesi & Ortalama & p değeri & Ki-Kare \\
\hline \multirow{4}{*}{ İyi Oluş } & $0-2500$ & 44,50 & \multirow{4}{*}{0,000} & \multirow{4}{*}{25,346} \\
\hline & $2501-5000$ & 169,75 & & \\
\hline & $5001-7500$ & 223,39 & & \\
\hline & $7501+$ & 166,50 & & \\
\hline \multirow{4}{*}{ Örgütsel Sinizm } & $0-2500$ & 204,00 & \multirow{4}{*}{0,006} & \multirow{4}{*}{25,346} \\
\hline & $2501-5000$ & 158,02 & & \\
\hline & $5001-7500$ & 215,34 & & \\
\hline & $7501+$ & 257,33 & & \\
\hline \multirow{5}{*}{ Aşırı Niteliklilik } & $0-2500$ & 138,50 & \multirow{4}{*}{0,000} & \multirow{4}{*}{25,346} \\
\hline & $2501-5000$ & 135,96 & & \\
\hline & $5001-7500$ & 231,73 & & \\
\hline & $7501+$ & 309,50 & & \\
\hline & Genel Kıdem & Ortalama & p değeri & Ki-Kare \\
\hline \multirow{5}{*}{ Aşırı Niteliklilik } & 2 yıldan az & 148,25 & \multirow{4}{*}{0,001} & \multirow{4}{*}{16,372} \\
\hline & $1-5$ yıl & 184,91 & & \\
\hline & $6-10$ yıl & 208,26 & & \\
\hline & $10 \mathrm{yll}+$ & 218,54 & & \\
\hline & Mevcut Kurumdaki Kıdem & Ortalama & p değeri & Ki-Kare \\
\hline \multirow{4}{*}{ Örgütsel Sinizm } & 2 yıldan az & 253,00 & \multirow{4}{*}{0,000} & \multirow{4}{*}{42,494} \\
\hline & $1-5 \mathrm{yll}$ & 190,23 & & \\
\hline & $6-10$ yıl & 156,26 & & \\
\hline & $10 \mathrm{yll}+$ & 217,50 & & \\
\hline
\end{tabular}




\section{Sonuç}

Kolayda örneklem ile elde edilen 400 çalışanlı verinin analizleri sonucu, araştırmanın dört hipotezinden üçü kabul görmüştür, birisi ise varsayılanın tersine bir yönde anlamlı olarak sonuç vermiştir.

Doğrulanan ilk hipoteze göre çalışanın aşırı nitelikli olduğu düşüncesi, kendisini örgüte karşı sinik tutumunu arttırabilmektedir. İlgili alanyazın incelendiğinde çalışanların kendilerini aşırı nitelikli olarak görmesi kendilerinde daha çok olumsuz tutum ve davranışlara yol açtığı gözlenmiştir (Yıldız ve Arda, 2018). Buna göre aşırı niteliklili olduğunu düşünen çalışanlar işyerinde sapkın davranışlara yönelebilir ve örgütüne karşı sinik tutum sergileyebilir (Luksyte vd., 2011; akt. Yıldız ve Arda, 2018). Bunun nedeni, faktör analizinde faktörlere ayrıldığı gibi çalışanın işini küçük görmesi ve kendini işine göre üstün görmesi, işine karşı olumsuz hislerini pekiştirmektedir. Buna bağlı olarak çalışanın işten ayrılma niyeti tetiklenebilmekte ve örgüte bağlılığı azalabilmektedir (Akın ve Ulukök, 2016). Sonuç olarak mevcut araştırmada ispatlanan ilgili hipotez yazındaki bulguları destekleyici yöndedir.

Diğer yandan çalışmalarda daha az da olsa aşırı nitelikliliğin uygun ortam yaratıldığında olumlu etkilerinin de olabileceği vurgulanmaktadır. Kendisini aşırı nitelikli gören çalışanın performansı artabilir, işten ayrılma niyeti azalabilir ve iş tatminsizliği törpülenebilir (Erdoğan ve Bauer, 2009; Erdogan vd., 2011). Çalışanın kendisini iyi hissetmesinin sonucu örgüte karşı olumsuz tutumunun körelmesi göz önünde bulundurularak aşırı nitelikliğin çalışanın iyi oluşunu tetikleyebileceği araştırmanın ikinci hipotezinde öne sürülmüştür. Analizler sonucu bu hipotez desteklenmiştir. Buna göre aşırı nitelikli çalışanların örgüte karşı olumlu tutum sergilemeleri için örgütün kendilerine elverişli ortam sağlamaları (çalışanların güçlendirilmeleri gibi) gerekmektedir (Erdoğan ve Bauer, 2009). Bu, örgüt için çalışandan verim alma konusunda çok önemlidir.

Araştırmanın üçüncü hipotezi ise kendilerini iyi hisseden çalışanların örgütsel sinizm algılarında azalış görüleceği yönündedir. Korelasyon analizine bakıldığında iyi oluş ile örgütsel sinizm ve faktörleri arasında zayıf ilişki olduğu görülse de regresyon analizi sonucunda anlamlı bir ilişki bulunmuş; ancak bu ilişkinin aksine pozitif yönde olduğu görülmüştür. Literatür incelendiğinde öznel iyi oluşun ilişkili olduğu bir diğer değişkenin mizah olduğu görülmektedir (Celso, Ebener ve Burkhead, 2003; İlhan, 2005; Panish, 2002; 
akt Özbay vd., 2012). Ancak mizah boyutunun aşırı olmasıyla bu yaklaşım yıkıcı bir hal almaktadır. Yıkıcı mizah tarzının olumsuz duygular oluşturduğu ve öznel iyi olma hâlini güçleştirebileceği belirtilmektedir (Özbay vd., 2012) Zira aşırıya kaçmış iyi oluş hali çalışanın örgütte var olan ve biteni mizahi bir bakış açısıyla algılamasına; hatta küçümsemesine yol açabilir. Böylece çalışan örgütüne karşı sinik bir hal alabilir. Bu bulgulardan yola çıkarak son olarak aşırı nitelikliliğin iyi oluş vasıtasıyla örgütsel sinizm algısını etkilediği hipotezi analizlerle onaylanmıştır.

Fark testleri de araştırmada elde edilen bulguların yazını desteklediğini göstermektedir. İyi oluş değişkeninin eğitim seviyesi arttıkça düştüğü görülmektedir. Türkçe literatürde tersine bulgu edinildiği görülmektedir (Güllü, 2018). Ancak bireyin aşırı niteliklilik algısının yüksek olduğu göz önünde bulundurulduğunda eğitim seviyesinin yüksek olması, yaptığı işin kendi seviyesine göre düşük olduğu algısını yaratacaktır; bu da çalışanın iyi oluşunu engelleyecektir.

Eğitimi seviyesinin artmasıyla örgüte duyulan sinizm ise artmaktadır. Benzer sonuç Türkçe literatürde de görülmektedir (Tokgöz ve Yllmaz, 2008). Bunun durum, eğitim seviyesinin yükselmesiyle kişinin kendisini üstün görmesi ve bulunduğu kuruma eleştirel yaklaşım içinde olmasından kaynaklanmaktadır.

Gelir seviyesi açısından farklar göstermektedir ki gelir seviyesi belli bir seviyeye kadar iyi oluşu pekiştirmekte ancak sonrasında etkisi azalmaktadır. Gelirin belli bir düzeyden sonra yüksek olması çalışanın işyerindeki diğer ihtiyaçlarını (duygusal ve manevi) karşılamayacağı etkisi baştaki gibi yüksek olmayabilir. Örgütsel sinizm de en yüsek gelir grubunda daha fazla hissedilmektedir. Bunun nedeni ise yüksek gelirlilerin bulunduğu işyerinden kendilerini giderek daha bağımsız hissedecek olmalarıdır. Literatüre bakıldığında yüksek maaşlı çalışanların daha çok harcama yaptıkları için gelirlerini daha çok yitirmekte ve hayal kırıklığına uğradıkları için sinizm düzeylerinin daha yüksek olduğu sonucu saptanmıştır (Delken, 2004; akt. Turan, 2011).

Son olarak kıdem süresine göre aşırı niteliklilik ve örgütsel sinizm açısından anlamlı farklar bulunmuştur. Sonuçlara göre, çalışanın aşırı niteliklilik algısı kıdem süresi ilerledikçe artmaktadır; çünkü kıdemle birlikte çalışanın deneyimi ve dolayısıyla nitelikliliği artmış olmaktadır. Kıdem ile aşırı niteliklilik ilişkisini destekleyecek bulgular literatürde de mevcuttur (Johnson ve Johnson, 1996; Maynard, Joseph ve Maynard, 2006; Erdogan ve Bauer, 2009). 
İşyerinde yeni olanlar ve ile işinde en yüksek kıdemli olan çalışanların hissettiği örgütsel sinizm daha yoğundur. Gerçekleştirilen çalışmalarda da mesleki kıdemleri az olan çalışanların örgüte sinik bakış açlarının daha yüksek olduğu söylenilmektedir. Bunun sebebi, iş yerinde yeni olan çalışanların yüksek beklentiler karşısında umduklarını ilk başta bulamamaları olabilmektedir (Kalağan ve Güzeler, 2010). Kıdem süresi belli bir sürenin üzerine çııınca da edinilen deneyimler sayesinde çalışanın kendine güvenin artmasıyla kuruma eleştirel bakış açısı geliştirmesi varsayılabilir.

Söz konusu çalışmanın geliştirilmesi için aşırı nitelikliğin örgütsel sinizmle ilişkisi bireysel faktörlerle (kişilik özellikleri gibi) açıklanabilir. Zira aşırı niteliklilik öznel bir algı olduğundan bireydeki kişisel farklılıklar bulunulan örgüte karşı kişinin tutumunu etkileyebilmektedir. Öte yandan çalışanın iyi oluşunu etkileyen örgütsel faktörler de gelecek çalısmalara dahil edilebilir. İyi oluş ile örgütsel sinizm arasındaki ilişkiyi değiştirebilecek birtakım değişkenler mevcut olduğu varsayılmaktadır Örneğin liderlik, örgüt kültürü gibi değişkenler ile araştırmanın boyutları zenginleştirilebilir. 


\title{
EXTENDED ABSTRACT
}

\section{The Mediating Role Of Employee Well Being On The Relationship Between Over Qualification And Organizational Cynicism}

\author{
Cihan Tinaztepe - Necmiye Tülin İrge \\ İstanbul Aydın University
}

Organizations prefer employees compatible with the level of qualification that they need to carry on business. Employees, whose qualifications like education, experience and skill are in accord with job qualifications, are ideal for organizations. However, this ideal is not always possible. A postgraduate employee positions him/herself differently on a job which requires only a graduate. This case is an example for over qualification which is defined as a "situation where individuals have surplus skills, knowledge, abilities, education, experience, and other qualifications that are not required by or utilized on the job."

The rapid change of the world with the current developments, together with the innovations in technology, have provided formed regular development and change strategies in the organizations. Along with this, changing expectations have created a need for qualified individuals who can work efficiently. The examples of the reasons for the emergence of organizational cynicism can be shown as unfair work distribution, failure to meet the expectations, failure to comply with contractual rules, unsuccessful leadership and management approaches, uncertainty in working hours .

Wellbeing is essentially how someone feels about various aspects of their life - their home life, their health, their relationships with others, their job and other activities. It's about whether they feel well and happy. In the workplace, employee wellbeing is about more than physiological or mental ill health it's about optimizing the health of all employees, not just reducing the numbers of staff who are diagnosed with medical conditions. Employee wellbeing also extends beyond health, and into happiness as well, and job satisfaction.

Employees with higher qualifications of education, experience and skills feel themselves overqualified while doing their jobs. Thus, they believe that 
they deserve more in return of their over qualification. Even though over qualification leads employee well being, this inefficacy of their organization causes them to exhibit cynic behavior. Regarding this relationship, this study generated the hypotheses below:

- H1: Thinking self as overqualified increases employee's cynic attitude against organization.

- H2: Thinking of self over qualification leads employees to feel well.

- H3: Feeling well, leads employees to lower their cynic attitude towards organization.

- H4: Over qualification affects organizational cynicism through employee well being.

The research was conducted with quantitative method. After determining the validity of measurement instruments of scales, the sample was examined through statistical calculations and hypotheses were tested. Lastly the demographic differences were indicated. For the research, convenience sampling method was used and White collar employees were reached. A total of 400 responds were received.

Factor analysis revealed two factors for over qualification just like in past studies in Turkish literature. In total, these factors explain $71 \%$ of over qualification variance. As for employee well being, after several iterations, it is reduced to three sub factors as satisfaction form work, satisfaction from life and self satisfaction. On the other hand in Turkish literature the variable was considered as a single factor. Lastly organizational cynicism was imposed to factor analysis and found to have three sub factors as in the literature (emotional, cognitive and behavioral cynicism). All the sub factors of all these variables were found to be internally consistent.

While for the first three hypotheses simple regression analysis was conducted, for the last hypothesis, multiple random sampling was used in order to test the mediation. Before correlation analysis, variables were imposed to normality test and it was seen that the data was not normally distributed as it was expected in many research. As a result of correlation analysis, while an average relation $(r=0,553)$ was found between well being and over qualification, satisfaction from life was found to be highly correlated with over qualification $(\mathrm{r}=0,876)$. 
First hypothesis, which was assuming the positive effect of over qualification on organizational cynicism, was supported after simple regression analysis $(\beta=0,106 ; p<0,05)$. Accordingly the explanation power of over qualification explaining organizational cynicism is $\mathrm{R} 2=0,010$. This means that over qualification explains $10 \%$ variance of organizational cynicism. The second hypothesis, which assumes that over qualification leads employee to feel well, was supported $(\beta=0,402 ; p<0,05, \mathrm{R} 2=0,406)$.

The third hypothesis was assuming a negative relationship between employee well being and organization cynicism; but this hypothesis was rejected because the relationship revealed as positive. In the last hypothesis a full mediation effect was determined, so it was accepted. Consequently expect one hypothesis, the rest was accepted.

Besides, difference tests were conducted in order to see the differences among demographic groups. As a result, it was seen that as education level gets higher, employee well being was reduced. Over qualification was mostly observed in graduates. In terms of income level, all the variables demonstrated significant differences. As income level increases, employee well being gets higher up to a level. Organizational cynicism was seen significantly in highest income level the most. Similar tendency was seen for over qualification. Accordingly as income level gets higher, perception of over qualification increases. Lastly as tenure gets longer, over qualification level increases. Whereas organizational cynicism is found to be high in the beginning of tenure, lower in middle tenure and re-increases as the time passes.

\section{Kaynakça / References}

Akbıyık B.S.Ü (2016). Algılanan aşırı nitelikliliğin iş performansına etkisi: Örgütsel desteğin biçimlendirici değişken rolü. Uluslararası Sosyal Araştırmalar Dergisi, 9(42), 1714-1715

Akbıyık, B.S.Ü, (2016). Otelcilik sektöründe algılanan aşırı nitelikliliğin görev performansına etkisi: Alternatif işfırsatlarının biçimlendirici değişken rolü. Journal of Tourism Theory and Research, 2(1), 21

Akbolat, M.vd. (2012). Sağlık çalışanlarının sinik davranışlar gösterme eğilimi. Kastamonu Üniversitesi İktisadi ve İdari Bilimler Fakültesi Dergisi, 4(2), 85-86

Akdağ F.G ve Çankaya, Z.C. (2015). Evli bireylerde psikolojik iyi oluşun yordanması. Mersin Üniversitesi Ĕ̈itim Fakültesi Dergisi, 11(3), 647 
Akdeniz, M. Z. (2016). Paternalistik liderlik veörgütsel adaletin çalışanlarm mutluluklarna olan etkisi: Să̆lık sektöründe bir uygulama. Yüksek Lisans Tezi, Bahçeşehir Üniversitesi

Akın, A. vd., (2017). Algılanan fazla niteliklilik, işe adanmışlık ve işten ayrılma niyeti arasindaki ilişkinin incelenmesi ve bankacllık sektörü üzerine bir araştırma. Uluslararası Sosyal Araştırmalar Dergisi, 10(54), 917.

Akın, A. ve Ulukök, E. (2016). Fazla nitelikliliğin bireysel ve örgütsel sonuçlarının güncellenmesine yönelik kavramsal bir değerlendirme. Journal of Business Research Turk, 8(4), 71-86.

Akyüz, İ. (2015). Sağlık çalışanlarının örgütsel sinizm düzeylerinin incelenmesi. International Journal of Economic and Administrative Studies, 62.

Ataç, L.O. ve Köse, S. (2017). Örgütsel Demokrasi ve Örgütsel Muhalefet İlişkisi: Beyaz Yakalllar Üzerine Bir Araştırma. İstanbul Üniversitesi İsletme Fakültesi Dergisi, 46(1), 119

Balay R. vd., (2013). Örgüt kültürü ve örgütsel sinizm ilişkisi. C.Ü. İktisadi ve İdari Bilimler Dergisi, 14(2), 127

Baron, R. M. ve Kenny, D. A. (1986). The moderator-mediator variable distinctionin social psychological research: Conceptual, strategic, and statistical considerations. Journal of Personality and Social Psychology, 51(6), 1173-1182.

Bilgiç, H.F. (2017). Liderlik ve örgütsel sinizm ilişkisi. Akdeniz Üniversitesi Sosyal Bilimler Dergisi, 2, 96-97

Bozkırlı, K. Ç. (2013). Prof.Dr. Kemal Yavuz ve Hacip böyle dedi Kutadgu Bilig'den seçmeler adlı eseri üzerine'. Uluslararası Türkçe Edebiyat Kültür Eğitim (TEKE) Dergisi, 2(2)

Brandes, P, Dharwadkar, R. ve Dean, J. W. (1999). Does organizational cynicism matter? employee and supervisor perspectives on work outcomes. Eastern Academy of Management Proceedings içinde (s.150-153). Outstanding Empirical Paper Award.

Celso, B.C., Ebener, D.J. ve Burkhead, H.(2003). Humor coping, health status, and life satisfaction among older adults residing in asisited living facilities. Aging and Mental Health, 7(6), 438-445.

Çam, M.S. (2019). Öyküleyici reklamlar ve tüketici sinizmi ilişkisi üzerine deneysel bir çalışma. Yayınlanmamış Doktora Tezi, Selçuk Üniversitesi, Sosyal Bilimler Enstitüsü, 134.

Çarıkçı, H.İ. vd., (2013). Örgüt çalışanları, örgütsel sinizm ve örgütsel bağlllık. Süleymen Demirel Üniversitesi Sosyal Bilimler Enstitüsü Dergisi, Büro Yönetimi Özel Sayısı, 181 
Çetinkaya, F.F. ve Özkara, B. (2015) Hizmet işletmelerinde psikolojik sözleşme ihlaller ve örgütsel sinizm ilişkisi: Kapadokya Bölgesi, 4 ve 5 ylddılı otel işletmelerinde bir araştırma. Kastamonu Üniversitesi İktisadi ve İdari Bilimler Fakültesi Dergisi, 9, 73

Çivilidağ A. (2015). Öğretim elemanlarında örgütsel sinizm ve işe yabanclaşma arasındaki ilişkide yaşam doyumunun aracı rolü. İş, Güç, Endüstri İlişkileri ve İnsan Kaynaklan Dergisi, 17(4), 269

Delken M. (2004). Organizational cynicism: A study among call centers. Unpublished master thesis, University of Maastricht.

Diener, E. (1994). Assessing subjective well-being: Progress and opportunities. Social Indicators Research, 31(2), 103-157.

Diener, E. ve Ryan, K., (2018) Öznel iyi oluş: Genel bir bakış. Çev.Gençer N., Hitit Üniversitesi Sosyal Bilimler Enstitüsü Dergisi, 3, 2624

Diener,E. (2000). Subjective well-being: The science of happiness and a proposal for a national index. American Pschologist, 55(1),34-43."

Dijk, H.V., Shanz, A. ve Alfes, K. (2019). Welcome to the bright side: Why, how, and when overqualificationenhances performance. Human Resource Management Review, 510

Doğan S. ve Uğurlu, C.T (2015). Okul yöneticilerinin etik liderlik davranışları ile öğretmenlerin örgütsel sinizm algıları arasındaki ilişki. Gazi Üniversitesi Gazi Eŏitim Fakültesi Dergisi, 34(3), 491-492

Duran, S. (2014). Zihinsel engelli bireylerin ebeveynlerine verilen piskoeğitimin öznel iyi oluş ve öz duyarlliğga etkisinin değerlendirilmesi. Yayınlanmamış Doktora Tezi, Marmara Üniversitesi, Sağlık Bilimleri Enstitüsü, İstanbul, s.36

Elçi, M. veKul, B. (2017). Kamu çalş̧anlarının etik iklim algilarının örgütsel sinizm tutumları üzerindeki etkisi. Çalışma İlişkileri Dergisi, 8(1), 122

Erdogan, B., Bauer, T. N., Peiró, J. M. ve Truxillo, D. M. (2011). Overqualified employees: Making the best of a potentially bad situation for individuals and organizations. Industrial and Organizational Psychology, 4(2), 215-232.

Erdoğan P. ve Bedük, A. (2013). Örgütsel sinizm ile örgütsel vatandaşlık davranışları arasındaki ilişki: Sağlk sektöründe bir araşltırma. Sosyoteknik Sosyal ve Teknik Araşttrmalar Dergisi, 6, 21

Erdoğan, B. and Bauer, N.T. (2009). Perceived overqualification and its outcomes: The Moderating role of empowerment. Journal of Applied Psychology, 94(2), 557

Erdost H., Karacaoğlu K., ve Reyhanoğlu M. (2007). Örgütsel sinizm kavramı ve ilgili ölçeklerin Türkiye'deki bir firmada test edilmesi. 15. Ulusal Yönetim ve Organizasyon Kongresi Bildiri Kitabı içinde (s.514-524). 
Eryllmaz A. (2009). Ergen öznel iyi oluş ölçeğinin geliştirilmesi. Türk Eğitim Bilimleri Dergisi, 7(4), 977

Gizlier, Ö. (2018). Çalışanlarn aşın niteliklilik alğlarnnn sonuçlarmı belirlemeye yönelik bir araştrma. Yayınlanmamış Yüksek Lisans Tezi, İstanbul Üniversitesi, Sosyal Bilimler Enstitüsü, İstanbul, 12

Gökyer, N. ve Türkoğlu, İ. (2018). The relationship between secondary school teachers' organizational support perceptions and their organisational cynisim attitudes. IJOESS, 9(34), 2355.

Görmen, M. (2017). Örgüt kültürününörgütsel sinizm tutumları üzerine etkisi. Bartn Üniversitesi I.I.I.B.F. Dergisi, 8(15), 366

Güllü, S. (2018). Employee happiness in sports businesses. International Journal of Social Sciences and Education Research, 4(3), 547-559.

Günay A. vd., (2018). Etik liderlik, işgören sesizliği ve özne iyi oluş arasındaki ilişkinin incelenmesi. International Journal of Economic and Administrative Studies, UIKKÖzel Sayisl, s.677

Head, T.C. (1989) The organizational and personal consequences of the overqualified employee. Texas AEM University, Doctoral Disserttation, 11-22

Hills, P. ve Argyle, M., (2002). The oxford happiness questionnaire: a compact scale for the measurement of psychological well-being. Personality and Individual Differences, 33, 1073-1082

İlhan, T. (2005). Öznel iyi oluşa dayal mizah tarzları modeli. Yayımlanmamış yüksek lisans tezi, Gazi Üniversitesi Eğitim Bilimleri Enstitüsü, Ankara

James, M.S.L. (2005). Antecedents and consequences of cynicism in organizations: An examination of the potential positive and negative effects on school systems. Doctoral Dissertation, College of Business, The Florida State University, 33-34

Johnson, G.J. and Johnson, W.R. (1999). Perceived overqualification and dimensions of job satisfaction: A longitudinal analysis. The Journal of Psychology,134(5), p.538.

Kalağan G. ve C. Güzeler. (2010). Öğretmenlerin örgütsel sinizm düzeylerinin incelenmesi. Pamukkale Üniversitesi Eŏitim Fakültesi Dergisi, 27, 83-97

Kanat, S. (2017). Güzel sanatlar vetasarım fakültesi öğrencilerinin problem çözmebecerisi, sinizm ve sürekli kaygı düzeyleri arasındaki ilişkinin incelenmesi. İ̈önü University Journal of Art and Design, 7(16), 253

Karacaoğlu K. ve Arslan, M. (2019). Algilanan aşırı niteliklilik ve iş tatmini ilişkisinde iyimserliğin aracı rolü: İstifa eden veya erken emekli olan subaylar üzerine bir araştrma. İktisadi ve İdari Bilimler Dergisi, 33(1), 116 
Karacaoğlu K. veİnce, F. (2012). Brandes, Dharwadkar ve Dean'in (1999) Örgütsel sinizm ölçeği Türkçe formunun geçerlilik ve güvenilirlik çalışması: Kayseri Organize Sanayi bölgesi örneği. Business and Economics Research Journal, 3(3), 79.

Karacaoğlu, K. ve Küçükköylü, C. (2015). İşgören sessizliğinin örgütsel sinizme etkisi: Kamu çalışanları üzerine bir araştırma. Ege Akademik Bakış Dergisi, 15(3), 403

Karcıoğlu M.S. ve Naktiyok, A. (2015). Örgütsel ortamda algilanan güven düzeyinin snizm üzerindeki rolü. Journal of Economics and Administrative Sciences, 17(1), 22

Kim, T.Y. at all (2009). Top management credibility and employee cynicism: Comprehensive model. Human Relations, 63(10), 1437

Kiremitçi, E. ve Coşkun, H. (2017). Mevsimsellik ve öznel iyi oluş arasındaki ilişkinin incelenmesi. AÏBÜ Sosyal Bilimler Enstitüsü Dergisi,17(2), 244

Kosa, G. (2019). Örgütsel sinizm ve iş doyumu ilişkisi: banka çalışanları üzerinde bir araştırma. Kafkas Üniversitesi İktisadi ve İdari bilimler Fakültesi Dergisi, 10(19), 186

Kuyumcu, B. ve Güven, M. (2012). Türk ve İngiliz üniversite öğrencilerinin duygularını fark etmeleri ve ifade etmeleri ile psikolojik iyi oluşları arasındaki ilişki. GEFAD / GUJGEF, 32(3), 590-591

Luksyte A. (2011). How can organisations maximize their overqualified employees potential? Examining organisationally-based strategies. Doctoral Disserttation, The Faculty of the Department of Psychology, University of Houston, 7-12

Luksyte, A., Spitzmueller, C., ve Maynard, D. C. (2011). Why do overqualified incumbents deviate? Examining multiple mediators. Journal of Occupational Health Psychology, 16(3), 279-296.

Martinez, P.G., Lengnick-Hall, M.L (2014) Mukta Kulkarni, Overqualified? A conceptual model of managers' perceptions of overqualification in selection decisions. Browse JournalsEBooks, 43(6), 959

Maynard, D. C., Joseph, T. A, Maynard, A. M. (2006). Underemployment, job attitudes, and turnover intentions. Journal of Organizational Behavior, 27(49), 509-536.

Maynard, D.C. ve Brondolo, E.M. (2015). I'm too good for this job: Narcissism's role in experienced of overqualification. Applied Psychology: An International Review, 60(1), 211

Oğrak A. ve Erol F. (2019). Yenilik, örgüt kültürü ve sinizm: Van YYÜ'de örnek bir uygulama. Ekev Akademi Dergisi, ICOAEF Özel Sayısı, 5-6

Osmanoğlu, D.E. ve Kaya, H.İ. (2013). Öğretmen adaylarının yükseköğretime dair memnuniyet durumlanı ile öznel iyi oluş durumlarının değerlendirilmesi: Kafkas Üniversitesi örneği. Sosyal Bilimler Enstitü̈üDergisi, 12, 48-49. 
Özbay, Y.vd. (2012). Üniversite öğrencilerinin öznel iyi oluşlarının duygusal düzenleme, mizah, sosyal özyeterlik ve başaçıkma davranışları ile yordanmass. Türk Ĕ̈itim Bilimleri Dergisi, 2, 325-345

Kökalan, Ö. ve Anaş, K. (2016) Çalışanların örgütsel sinizm tutumlarının işe yabanclaşmaları üzeine etkisi: Vakuf üniversiteleri üzerine bir çalısma. bigi ekonomisi ve yönetimi dergisi, 11(2), 100-101

Özkanan A. (2018). Algilanan aşır nitelikliliğe iki yönlü bakş̧: Çalsşan-amir değerlendirmesi. Finans Ekonomi ve Sosyal Araştırmalar Dergisi, 3(4), 665-666

Özler D.E. vd., (2010). Örgütlerde sinizm güvensizlikle mi bulaşrr?. Organizasyon ve Yönetim Bilimleri Dergisi, 2(2), 54-55

Öztürk, Y. (2017). Ergenlerde Dindarlık ile Öznel ḣyi Oluş Arasındaki ilişkinin İncelenmesi: Çarşamba örneği. Yayınlanmamış Yüksek Lisans Tezi, Hitit Üniversitesi, Sosyal Bilimler Enstitüsü, Çorum, 33

Panish, R. J. (2002). Life satisfaction in elderly. Anpublished Doctora Dissertation, California School of Professional Psychology at Alemeda.

Rebecca L. ve Volpe, B.A., (2011). Moral disterss, cynicism and interlnalization of values in nurses. Saint Louis University, Doctoral Dissertation, 43-44

Reyhanoğlu, M. ve Yılmaz, H. (2017). Örgütsel güvenin sağlanmasnda sinizmin etkisi: Havalimanı Güvenlik Memurları örneği. Trakya Üniversitesi Sosyal Bilimler Dergisi, 19(2), 302-303

Satan A. A. , (2014). Dini inanç ve bilişsel esneklik düzeylerinin öznel iyi oluş düzeylerine etkisi. 21. Yüzyl Ĕ̈itim ve Toplum Dergisi, 3(7), 57

Sipahi, B. Yurtkoru, E. S. ve M. Çinko. (2008). Sosyal bilimlerde SPSS'le veri analizi. Beta Yaymları

Şahin, G.N. (2011). Üniversite öğrencilerinin kendini açma, öznel iyi oluş ve alģladkklan sosyal destek düzeylerinin karşlaş̧trrlması. Yayınlanmamış Yüksek lisans Tezi, Dokuz Eylül Üniversitesi, Eğitim Bilimleri Enstitüsü, 26

Tinaztepe, C. (2012). Örgüt içi etkin iletişimin örgütsel sinizme etkisi. Organizasyon ve Yönetim Bilimleri Dergisi, 4(1), 56

Tokgöz N., Yılmaz H. (2008). Örgütsel sinizm: Eskişehir ve Alanya'daki otel işletmelerinde bir uygulama. Anadolu Üniversitesi Sosyal Bilimler Dergisi, 8(2), 283-305

Turan, S. (2011). Küreselleşme sürecinde örgütsel değişimi etkileyen bir unsur olarak örgütsel sinizm ve Karaman ili kamu kurumlarnnda bir çalısma. Yayınlanmamış Yüksek Lisans Tezi,Sosyal Bilimler Enstitüsü, Karamanoğlu Mehmet Bey Üniversitesi, 95 
Usta, I. (2016). Liderlik davranışının çalışanların öznel iyi oluşlan ve işe yabanculaşmaya etkisi: Bir alan araştırması. Yayınlanmamış Doktora Tezi, Trakya Üniversitesi, Sosyal Bilimler Enstitüsü, 70

Uysal, H.T. (2014). İşgören performansı açısından çalışma psikolojisinin örgütsel sinizme etkisi. Uluslararası Sosyal Araştırmalar Dergisi, 7(29), 837.

Yalçınkaya A. (2014). Türkiye'de örgütsel sinizm: 2007-2012 yılları arasındaki çalışmalar üzerine bir değerlendirme. İş Güç Endüstri İlişkileri ve Insan Kaynaklan Dergisi, 16(3), 109

Yang,W. vd. (2015). Career adaptability and percieved overqualification among chinese human resource management professionals. Journal of Vocational Behavior, 90, 154-1

Yeşiltaş, A , Şahin, S, ve Serezli, G . (2019). Çalişan mutluluğunun ve işe bağliliğin örgüt performansina etkisi. Mehmet Akif Ersoy Üniversitesi Sosyal Bilimler Enstitüsü Dergisi

Yıldız B. ve Arda, Ö.A. (2018). Aşırı nitelikliliğin yenilikçi iş yeri davranışları üzerindeki etkisinde kolektif şükran modeli. Yönetim ve Ekonomi Araştırmalan Dergisi, 16(2), 145.

Yıldız, B., Özdemir, F., Habib, E., ve Caki, N. (2017). The moderating effect of collective gratitude on the overqualification: Turnover intention relationship. Journal of Organizational Behavior Research, 2(2), 40-61.

Yücel İ. ve Çetinkaya, B. (2015). Örgütsel sinizm ile örgütsel bağlllık arasındaki ilişki ve çalışanların yaşının bu ilişkiüzerindeki etkisi: Bazen hoşlanmasak da kalmak zorunda olabiliriz! Atatürk Üniversitesi Sosyal Bilimler Enstitüsü Dergisi, 19 (3), 251

Zhang, M.J., Law, K.S. ve Lin, B. (2017). You think you are big fish in a small pond? Perceived overqualification, goal, orientations, proactivitiy at work. Journal of Organizational Behavior, 37, 61 .

\section{Kaynakça Bilgisi / Citation Information}

Tınaztepe, C. ve İrge, N. T. (2021). Çalışanın aşırı niteliklilik özelliği ile örgütsel sinizm ilişkisinde iyi oluşunun aracı etkisi. OPUS-Uluslararası Toplum Araştırmaları Dergisi, 17(33), 303-331. DOI: 10.26466/opus.804170 